\title{
A surveillance of needle-stick injuries amongst student nurses at the University of Namibia
}

\author{
Authors: \\ Louis Small \\ Louise Pretorius \\ Althea Walters ${ }^{1}$ \\ Maria J. Ackerman ${ }^{1}$ \\ Affiliations: \\ ${ }^{1}$ Department of Nursing, \\ University of Namibia, \\ Namibia \\ Correspondence to: \\ Louis Small \\ Email: \\ Ismall@unam.na \\ Postal address: \\ Private Bag 13301, \\ Pioneerspark, Windhoek, \\ South Africa \\ Dates: \\ Received: 13 Oct. 2009 \\ Accepted: 04 May 2011 \\ Published: 10 Oct. 2011 \\ How to cite this article: \\ Small, L., Pretorius, L., \\ Walters, A. \& Ackerman, \\ M.J., 2011, 'A surveillance \\ of needle-stick injuries \\ amongst student nurses at \\ the University of Namibia', \\ Health SA Gesondheid 16(1), \\ Art. \#507, 8 pages. http:// \\ dx.doi.org/doi.10.4102/hsag. \\ v16i1.507
}

C) 2011. The Authors. Licensee: AOSIS OpenJournals. This work is licensed under the Creative Commons Attribution License.
Needle-stick injuries have the potential to change a student nurse's life; yet they are dealt with covertly and many go unreported. This could create difficulties when evaluating a curriculum, because potential risk issues in nursing education might go undetected. In addition, needlestick injuries are inherently preventable occupational health hazards. The fact that there has been, until now, no information available on the incidence of, and context in which needlestick injuries occur amongst student nurses in Namibia, is of particular concern for nurse educators in that country. The purpose of this study was therefore to determine the incidence of needle-stick injuries and to describe the context of their occurrences. A framework known as Haddon's matrix made it possible to approach this survey from both an occupational and a nursing education perspective.

The questionnaire was completed by 198 students and it was found that, during 2008 alone, $17 \%$ of student nurses sustained needle-stick injuries, but only $55 \%$ of these reported it. In addition, in $55 \%$ of the occasions on which the student nurses were injured, they were not accompanied by a registered nurse. The recommendations made are based on the three phases of Haddon's matrix, namely pre-injury, injury and post-injury phases. These recommendations focussed on student accompaniment by registered nurses, the completion of reflective exercises, sensitisation sessions before placement in clinical areas, as well as the utilisation of independent student counsellors.

Enige naaldprik-insident kan 'n groot omwenteling in 'n student-verpleegkundige se lewe te weeg bring. Ten spyte hiervan word sodanige insidente nie openlik hanteer nie, en dikwels word dit nie eers gerapporteer nie. Dit mag egter kurrikulering-evaluerings kompliseer want potensiële risiko-aspekte in verpleegonderwys mag dalk nie geidentifisser word nie. Naaldprik-ongelukke is in wese beroepsgesondheidsaspekte, wat inherent voorkombaar is. Dit was dan ook ' $n$ bron van kommmer onder verpleegopvoeders in Namibië, aangesien geen inligting beskikbaar was oor die voorkoms en konteks van naaldprik-ongelukke onder student-verpleegkundiges in Namibië nie. Die doel van hierdie studie was dus on die voorkoms en konteks waarbinne naaldprik-ongelukke plaasvind te beskryf. Daar was reeds a raamwerk beskikbaar, naamlik die Haddon-matriks. Diè raamwerk het dit moontlik gemaak om die opname te benader vanuit sowel ' $n$ beroepsgesondheids-perspektief as ' $n$ verpleegopvoedkundige perspektief.

Die vraelys is voltooi deur 198 studente en van die bevindings was dat gedurende 2008 alleen, $17 \%$ van die student-verpleegkundiges naaldprik-insidente gehad het, maar dat slegs $55 \%$ van die beseerdes dit aangemeld het. Daar is ook gevind dat in $55 \%$ van die gevalle, hulle nie deur ' $n$ geregistreerde verpleegkundige vergesel was nie. Aanbevelings wat gemaak is, is gebaseer op die drie fases van die Haddon-matriks, naamlik die voor-beserings-fase, die beseringsfase en die na-beserings-fase. Die aanbevelings is gefokus op student-begeleiding, reflektiewe oefeninge, sensitiseringsessies voor die plasings in kliniese areas, asook ondersteuning van 'n onafhanklike berader.

\section{Introduction}

Student nurses in Namibia are expected to administer medicines to patients from their first year of training. This is performed by a variety of means such the intramuscular method. This specific skill, namely the intramuscular administration of medicines, is practised under supervision in a simulation laboratory as early as the first semester of the first year of training. From then on the student nurses have the opportunity to administer medication under the supervision of a registered nurse. This skill is constantly honed during subsequent years.

This method of medicine administration has an anatomical consideration imbedded in the teaching and supervision. This consideration is related to regional anatomical structures, such 
as nerves, that have to be avoided and, historically, it formed the critical point when teaching this skill to students. During the late-1980s, however, another consideration was added to the anatomical consideration, namely the possibility of being infected with the human immunodeficiency virus (HIV) as a result of an accidental needle-stick injury. There is also the possibility of contracting Hepatitis B (HBV) and Hepatitis C (HCV).

Despite this added 'consideration', the average risk of contracting HIV or AIDS following percutaneous exposure to HIV-infected blood in health-care settings is approximately 3 per 1000 injuries, and has never been recorded for incidences where HIV blood came into contact with intact skin. Although there is a relatively minimal risk involved with regard to HIVinfection, the possibility of contracting HBV-infections and $\mathrm{HCV}$-infections remains, which is in fact more probable than contracting HIV (Leliopoulou, Waterman \& Chakrabarty 1999:53-59). The probability that a single needle-stick will result in disease is 300 chances in 1000 for HBV, and 20-50 chances in 1000 for $\mathrm{HCV}$, which is considerably higher than the documented 3 per 1000 injuries for HIV (E-Facts 2011:2; Wilburn 2004:2)

Although the risks of being exposed to these blood-borne viruses are low, they nevertheless do exist and, should they be transmitted, the result could be a chronic health disorder(s) and even death, as well as complicated psychological effects. The student nurses are thus sensitised to these risks from the outset of their training. However, although they might have the knowledge on how to prevent accidental injuries, their level of skills development, specifically first-year nursing students, might not yet be optimal. This places a definite responsibility on the nurse educators and mentors in the clinical setting. Nurse educators are in part responsible for the actions of the students and are subject to liability for negligent acts such as inadequate supervision of students in the clinical setting (Meyer \& Van Niekerk 2008:109).

Nurse educators are therefore required to assess the realities of the clinical situation; not only for the legal implications of their teaching, but also because of the ethically implications. In addition, they have to ensure that curriculum modifications are implemented and quality control guidelines are strengthened.

In attempting to address this problem for the purposes of curriculum modification and implementation, it was discovered that objective data on needle-stick injuries amongst student nurses were not available.

Accidental needle-stick injuries are not uncommon amongst student nurses in a clinical setting, although the chances are slim of actually acquiring an infection from such injuries. Any infections, should they occur, resort under the nomenclature of nosocomial infections (University of Namibia 2007:487), and have been identified and put into perspective in the introduction to this article. Infections are 'harmful' to the student nurse, and even though infections acquired from needle-stick injuries rarely occur, the actual injuries per se still cause psychological harm. Thus, from an educational perspective, the student nurse should be protected from harm, whether physical or psychological. This aspect is also imbedded in the view of the International Labour Organization (ILO) which states that all appropriate measures should be taken to prevent, reduce or eliminate risks to the health of nursing personnel (Nursing Matters 2011:2). This call to protect the student nurse is partly and indirectly addressed in the development of meso-curricula for nursing. One activity to be completed during the development of the meso-curriculum is the assessment of clinical facilities (Meyer \& Van Niekerk 2008:54-55).

The assessment of clinical facilities is broadly based on the type of facility and the number and qualifications of the nursing and clinical support personnel. This assessment alone would be inadequate to cover the entire context in which needle-stick injuries might occur and also does not address the context in its entirety. As indicated, the framework, Haddon's matrix, within which this study is situated allows for wider and more thorough context coverage. The role of the nurse educator in protecting the student nurse could be more adequately described in terms of the concepts proposed in Haddon's matrix (University of Minnesota 2009:1). These concepts are the pre-injury phase, the injury phase and the post-injury phase.

The pre-injury phase could be regarded as firstly ensuring a safe environment where student nurses could acquire the necessary skills to handle, use and dispose of sharps with minimal risk for possible needle-stick injuries, and secondly to teach safer methods in this regard.

A safe clinical learning environment should not expose student nurses to unforeseen injuries. This means that adequate supervision and mentoring should be available. The clinical rotation of student nurses is managed by a clinical unit that ensures the placement of students in clinical areas that have been approved by the Namibia Nursing Council. This approval is based in part on the availability of registered (qualified) nurses to accompany the students during their clinical placements in these areas. This aspect is emphasised by Uys and Gwele (2005:81), who state that it is important to choose a clinical setting where there is an adequate number of registered nurses on the staff.

Safer methods specifically include skills related to the administration of intramuscular medications. It also entails adhering to proven guidelines such as those published by the International Council of Nurses (Nursing Matters 2001:2). These guidelines are logical and easy to follow and those that are relevant to nursing education concern the disposal of used syringes and needles, the monitoring of injuries, safe workplaces, and provision for post-exposure prophylaxis. The disposal of used syringes and needles plays a major role in needle-stick injuries, and the skills needed to prevent injuries occurring as a result of the incorrect disposal of syringes and needles are emphasised in the nursing curriculum at 
the University of Namibia. This emphasis occurs from the moment the administration of medicines is taught and is strengthened in related subjects such as microbiology where infection-control principles are taught, for example avoiding the re-sheathing of needles (Engelkirk \& Burton 2007:209).

The injury phase focuses mainly on the incidence rate. The incidence rate provides an indication of the magnitude of needle-stick injuries and provides justification for any curriculum amendments. In addition, the presence of registered nurses during needle-stick injuries is analysed. This aspect differs from the availability of registered nurses, because the emphasis would be on supervision. Supervision by lecturers is not always possible, and this function is therefore delegated to the registered nurses in the clinical setting (Meyer \& Van Niekerk 2008:170). The injury phase also focuses on the clinical area in which a specific needle injury occurs. This aspect is integral to the evaluation of a curriculum, namely to determine whether the clinical setting is appropriate for the learners (Uys \& Gwele 2005:117).

The post-injury phase deals with a variety of focus areas, namely the reporting of needle-stick injuries, the testing that takes place post-injury, as well as the treatments received and the availability of counselling. Support in these areas is well documented in the literature (Trim 2004:1-9; University of Minnesota 2009:1-5).

\section{Problem statement}

There has been no information available on the incidence of, and context in which, needle-stick injuries occur among student nurses in Namibia. This is of particular concern for nurse educators in the country as provision has to be made in the curricula for a safe environment during clinical placements.

\section{Frame work}

A framework that seemed appropriate to this study is Haddon's matrix (University of Minnesota 2009:1). This matrix is based on the epidemiological model and focuses on a pre-injury phase, an actual injury phase, and a post-injury phase. This approach recognises that different factors operate in each phase, and that any possible intervention(s) should take these factors into consideration. Haddon's matrix has been integrated with an outline of the questionnaire (Table 1) and specific objectives were stated to focus on the study.

\section{Objectives of the study}

The objectives of the study were:

- to determine the incidence of needle-stick injuries amongst student nurses and the actions taken following a needlestick injury

- to describe the context in which such injuries occur

- to formulate recommendations for the clinical accompaniment of nursing students, to submit to curriculum committees.

\section{Significance of the study}

The significance of this study is the confirmation once again of the complimentary roles and functions of the nurse educator and the registered nurse in the clinical setting. Both groups are needed to assist student nurses in ways on how to practice safe medication administration. By creating awareness on the dangers of a needle-stick injury, safe practices will be enhanced and dangers in transmitting viruses will be eliminated.

\section{Research method and design Design}

A quantitative descriptive design was used. The study was contextual, because only nursing students from the Windhoek campus were included.

\section{Population and sampling}

The study population comprised all the student nurses from first-year to fourth-year (a total of 333) enrolled in the Faculty of Medical and Health Sciences, specifically at the Windhoek

TABLE 1: Outline of the questionnaire.

\begin{tabular}{|c|c|c|c|}
\hline $\begin{array}{l}\text { Focus area of } \\
\text { questionnaire }\end{array}$ & Specific item (Question) & $\begin{array}{l}\text { Correlation of Haddon's matrix } \\
\text { with the questionnaire }\end{array}$ & Comments \\
\hline \multirow[t]{5}{*}{$\begin{array}{l}\text { Incidence rate and } \\
\text { actions taken following } \\
\text { a needle-stick injury }\end{array}$} & Incidence rate & Injury phase & $\begin{array}{l}\text { The incidence rate (morbidity rate) forms the hallmark } \\
\text { of epidemiology and infection control (Engelkirk \& } \\
\text { Burton 2007:175). }\end{array}$ \\
\hline & Reporting the needle-stick injury & Post-injury phase & $\begin{array}{l}\text { This is necessary for accurate, official reports on which } \\
\text { to base recommendations. }\end{array}$ \\
\hline & Being tested after the needle-stick injury & Post-injury phase & $\begin{array}{l}\text { This item might indicate whether reported official } \\
\text { epidemiological statistics are totally reliable. }\end{array}$ \\
\hline & Being treated after needle-stick injury & Post-injury phase & $\begin{array}{l}\text { The need for health education as well as counselling is } \\
\text { addressed by this item. }\end{array}$ \\
\hline & Being counselled after a needle-stick injury & Post-injury phase & $\begin{array}{l}\text { The need for health education as well as counselling is } \\
\text { addressed by this item. }\end{array}$ \\
\hline \multirow[t]{3}{*}{$\begin{array}{l}\text { The context of needle- } \\
\text { stick injury occurrence }\end{array}$} & Academic year & $\begin{array}{l}\text { Pre-injury phase: } \\
\text { - occupation type } \\
\text { - awareness of surroundings } \\
\text { - perception of danger }\end{array}$ & $\begin{array}{l}\text { This item is aimed at identifying the 'vulnerable' } \\
\text { academic years. First-year nursing students are not } \\
\text { necessarily the most vulnerable because they are } \\
\text { often more strictly supervised in contrast with senior } \\
\text { students who may be left unsupervised. }\end{array}$ \\
\hline & $\begin{array}{l}\text { Presence of registered nurse during needle- } \\
\text { stick injury }\end{array}$ & Injury phase & This item focused on the extent of supervision. \\
\hline & $\begin{array}{l}\text { Clinical areas in which needle-stick injuries } \\
\text { occurred. }\end{array}$ & Injury phase & This item focused on the extent of supervision. \\
\hline
\end{tabular}

Please see full reference list of this article: Small, L., Pretorius, L., Walters, A. \& Ackerman, M.J., 2011, 'A surveillance of needle-stick injuries amongst student nurses at the University of Namibia', Health SA Gesondheid 16(1), Art. \#507, 8 pages. http://dx.doi.org/doi:10.4102/hsag.v161.507 
campus of the University of Namibia during 2008. All the students were included and consequently no sampling techniques were used.

\section{Data treatment}

A self-report (structured questionnaire) was developed. This instrument was based on curriculum planning considerations with a focus on the incidence of needle-stick injuries and current clinical practice 'realities'.

\section{Data collection and analysis}

The questionnaires were distributed amongst 333 nursing students during November 2008 as part of their final course evaluation sessions. They completed the questionnaires during this one session and returned them immediately to the researcher. A total of 198 completed questionnaires were returned and the response rate for the different year groups noted (Figure 1). Descriptive statistics were used in the analysis of the data.

\section{Results}

The highest response rate was from the first-year nursing students, namely 83 in total. In addition, 30 second-year, 47 third-year and 38 fourth-year students completed the questionnaires. In total 25\% $(n=49)$ of these students sustained needle-stick injuries during their academic training.

In analysing the incidence rate of the needle-stick injuries, two types of responses were made provision for, namely their responses on what have happened during the year of the data collection, which was the year 2008, and a subsequent reflection on earlier injuries. In addition, there were focused on the year of the study, because it would be easier to recall the number of injuries for this period than for previous years.

The incidence of needle-stick injuries sustained by student nurses was reported to be as high as $17 \%$ for 2008 alone $(n=34)$. If the representation of the different year groups is taken into consideration, then an overall picture can be put together (Table 2).

It is evident that only $14.4 \%$ of all first-year nursing students sustained a needle-stick injury during 2008 (Table 2), but their overall contribution to the total number of needle-stick injuries for the same year was noticeably higher than the other academic year groups. In this instance they sustained somewhat more than $35 \%$ of all needle-stick injuries.

This finding could also be related to Haddon's matrix, according to which the pre-injury phase is influenced by an awareness of the surroundings, as well as knowledge of preventative measures (University of Minnesota 2009:2). In this study 'awareness of the environment' could be equated with 'length of clinical experience', which, in the case of firstyear nursing students, could safely be assumed to be less than the other academic years. With regard to knowledge of preventative measures, first-year nursing students would not have acquired the same degree of cognitive and psychomotor development.
TABLE 2: Representation based on population participation in study $(N=198)$ and number of needle-stick injuries for $2008(N=34)$.

\begin{tabular}{|c|c|c|c|c|}
\hline \multirow[t]{2}{*}{$\begin{array}{l}\text { Academic } \\
\text { year group }\end{array}$} & \multirow[t]{2}{*}{$n$} & \multirow[t]{2}{*}{$\begin{array}{l}\text { Needle-stick } \\
\text { injuries }\end{array}$} & \multirow{2}{*}{$\begin{array}{c}\begin{array}{c}\text { Sustaining a } \\
\text { needle-stick } \\
\text { injury }\end{array} \\
n \\
\end{array}$} & \multirow[t]{2}{*}{ Total } \\
\hline & & & & \\
\hline First-years & 83 & 12 & 14.4 & 35.3 \\
\hline Second-years & 30 & 7 & 23 & 20.6 \\
\hline Third-years & 47 & 9 & 19 & 26.5 \\
\hline Fourth-years & 38 & 6 & 15.7 & 17.6 \\
\hline Total & 198 & 34 & - & 100 \\
\hline
\end{tabular}

Source: Authors' original data

$N$, Given as means of total population; $n$, Given as a means of number. Values are given as percentage

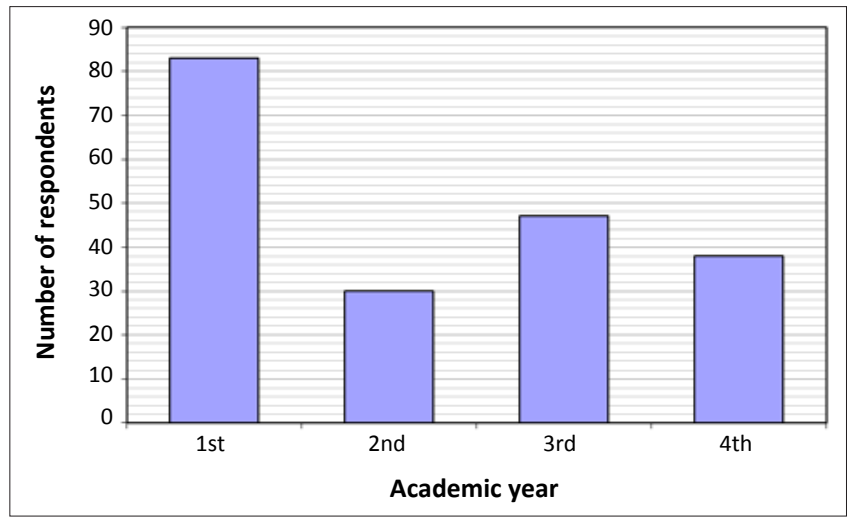

Source: Authors' original data

$n$, Given as a means of number.

FIGURE 1: The response rate per academic year group $(n=198)$.

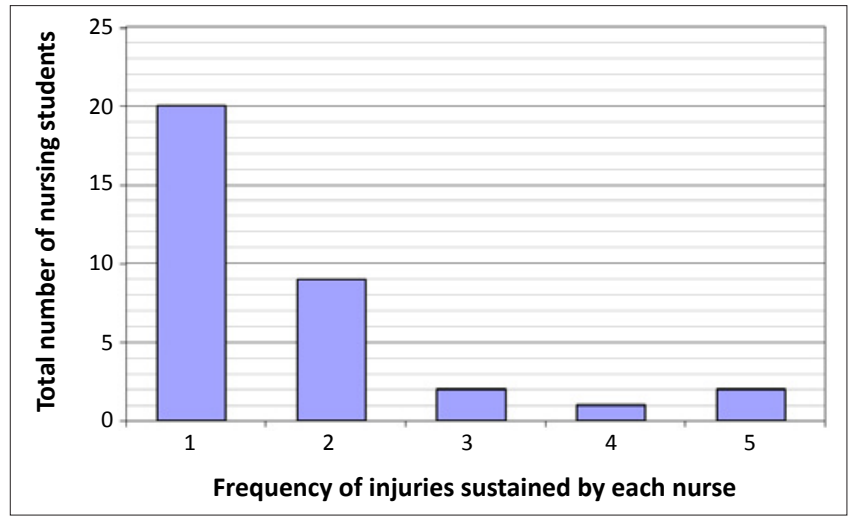

Source: Authors' original data

$n$, Given as a means of number.

FIGURE 2: The number of needle-stick injuries sustained during 2008 by each of the injured nursing students $(n=34)$.

During 2008, 58.8\% ( $n=20)$ of the students who had been injured, injured themselves only once, compared to $26.5 \%$ $(n=9)$ of the students who had sustained two injuries for the same period (Figure 2). Two students had sustained three injuries, one student had sustained four injuries and two students had sustained more than four injuries. Based on Haddon's matrix, an assumption would have been that no students should have sustained a secondary needle-stick injury, because education should have been provided during the post-injury phase (University of Minnesota 2009:4).

The discussion above only focused on the 2008-data. Further analysis of the needle-stick injuries before 2008, reveals that a further 15 students reported needle-stick injuries that had 
occurred before 2008. This increases the number of injuries from 34 to 49 , signifying that $25 \%$ of all student nurses at the Windhoek campus of the University of Namibia sustained a needle-stick injury during their training. This result is higher than the previously reported statistics in Namibia. In the available statistics it was found that the incidence of needlestick injuries in 1991-1999 for student nurses in Namibia was 15\% (University of Namibia 2007:503). A study carried out in South Africa during 2003 revealed that $16.4 \%$ of health workers reported sustaining needle-stick injuries (Bodkin \& Bruce 2003:26). These health professionals included registered nurses, enrolled nurses, medical practitioners and medical and nursing students.

Twenty-two ( $n=22 ; 45 \%)$ of those students who sustained needle-stick injuries never reported it, whereas one student reported one incident but not the second (or third incident).

According to Haddon's matrix, the reporting of injuries is described as being part of the post-injury phase, and is regarded as a necessary activity of this phase in order to initiate preventative measures (University of Minnesota 2009:2). In terms of Haddon's matrix, the inference here is that the initiation of effective preventative measures would not have been possible.

These findings are similar to those reported by Bodkin and Bruce (2003:26), who stated that only 53.8\% of injured health professionals reported their needle-stick injuries. Many reasons are provided for not reporting needle-stick injuries, some of which include an inaccurate assessment of sourcepatient risk factors, complacency and fear of a positive result (Trim 2004:1).

The University of Namibia guidelines stipulate that all injuries should be reported to a designated supervisor as soon as possible (University of Namibia 2007:507).

The post-injury phase of Haddon's matrix emphasises the need for testing to be conducted. It is emphasised that all medical evaluations should be made available to the injured persons; in this case the students who sustain needle-stick injuries (University of Minnesota 2009:5).

Twenty-seven ( $n=27 ; 55 \%)$ of the students who sustained needle-stick injuries were tested for HIV and AIDS. When a needle-stick injury is sustained, blood has to be collected from the injured worker for virology (HIV, HBV, HCV), (Ziady \& Small 2004:1870). In Namibia, the students who were injured and who were tested had to be re-tested, according to the policy of the Ministry of Health and Social Services (University of Namibia 2007:160), at 6 weeks, 3 months and 6 months to make sure that there was no HIV transmission. In this study it is evident that a large number of students, namely $45 \%(n=22)$, were not tested.

It would appear from the literature on the subject that, following injury, many nurses and doctors would rather not know their status because of the potentially devastating effect a positive result could have on their career (Trim 2004:2).

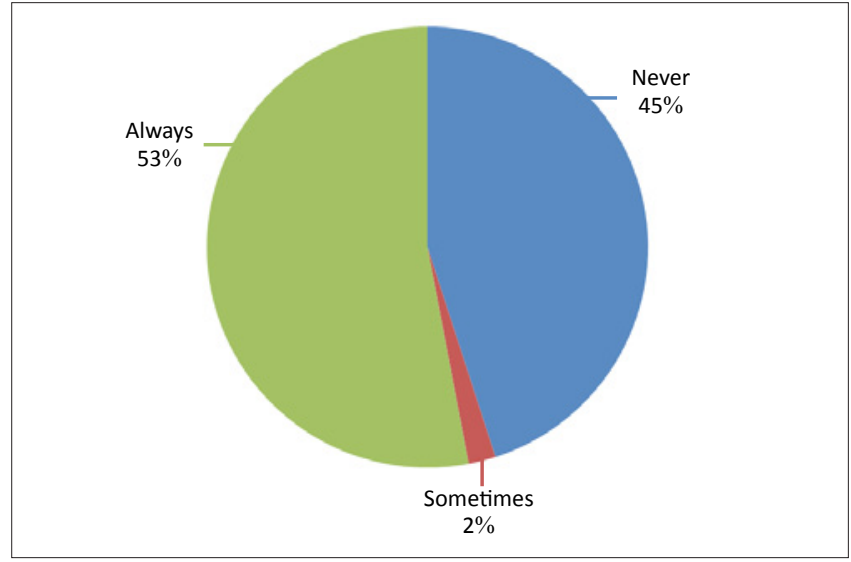

Source: Authors' original data $n$, Given as a means of number.

FIGURE 3: The number of reported needle-stick injuries $\left(n=49^{1}\right)$.

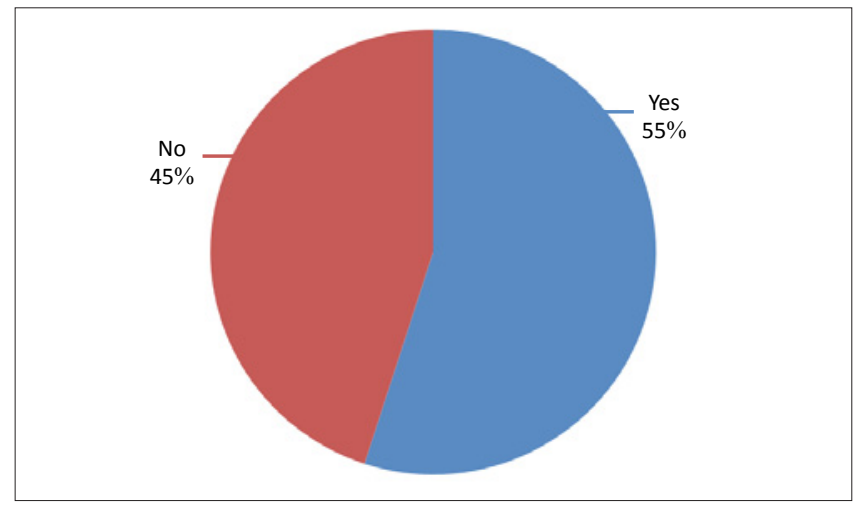

Source: Authors' original data

$n$, Given as a means of number.

FIGURE 4: Percentage of students who were tested for HIV and AIDS after the needle-stick injury $(n=27)$.

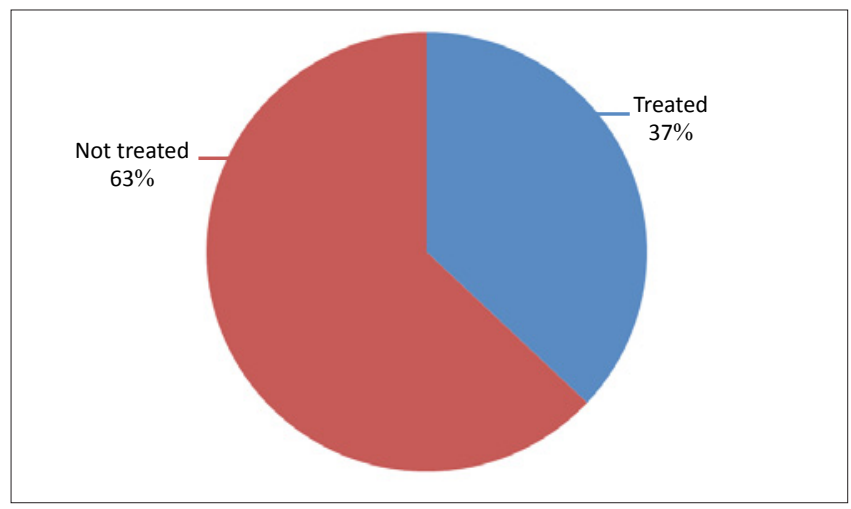

Source: Authors' original data

$n$, Given as a means of number.

FIGURE 5: Percentage of students who received treatment after they reported their needle-stick injury $(n=49)$.

Thirty-one $(n=31 ; 63 \%)$ of those students who sustained needle-stick injuries did not receive any treatment, whereas eighteen $(n=18 ; 37 \%)$ did receive treatment after the injury. According to Haddon's matrix, the post-injury phase included the activity of 'Countering the damage already done'. In this study, it would not have been possible to intervene optimally.

1.This includes the number of students for $2008(n=34)$ and those $(n=15)$ who were injured before 2008 . 
In a study conducted in South Africa, it was noted that post-exposure prophylaxis was taken by $50 \%$ of health professionals that sustained needle-stick injuries (Bodkin \& Bruce, 2003:26).

The types of clinical area could be correlated with both the pre-injury and the injury phases of Haddon's matrix. In terms of this matrix, the pre-injury phase includes an awareness of surroundings, which could be equated with the clinical areas in the sense that not every clinical area is identical, and some might require more intensive supervision than others to prevent needle-stick injuries. During the injury phase, one of the components is the 'speed with which an activity is carried out'. It is possible that nursing reaction times will increase in emergency situations such as those that occur in trauma units and critical care units. 'Speed' might also be a consideration when a large number of clients or patients have to be attended too, for example in clinics (University of Minnesota 2009:2).

In this study, $27 \%(n=17)$ of all injuries occurred in the clinics whereas $27 \%$ ( $n=17$ ) occurred in the medical wards. As early as their first year (students from the diploma programme) and second year (for the degree), nursing students in Namibia are also allocated to community clinics.

A study carried out in South Africa during 2003 revealed that most of the incidences of needle-stick injuries occurred in the intensive care unit, followed by the emergency unit, the operating room, labour wards, and the medical wards (Bodkin \& Bruce 2003:26).

In the Namibian study the student nurses were not allocated to the intensive care unit, and clinical rotations to the emergency department are only scheduled during their fourth year of training. Also, as students, they would not be allowed to use any sharp instruments in the operating room.

Twenty-two $(n=22 ; 45 \%)$ of the nursing students received counselling after sustaining a needle-stick injury. Seeking and receiving counselling form part of the post-injury phase of Haddon's matrix (University of Minnesota 2009:2).

Counselling should be provided, based on the general assumption of this matrix, as well the requirement(s) contained in the University of Namibia's HIV and AIDS resource guide, that at least two counselling sessions should be provided after needle-stick injuries (University of Minnesota 2009:2; University of Namibia 2007:174). It is, therefore, not clear why some students did not seek counselling because counsellors were readily available. No question was formulated on the number of counselling sessions.

On the question of whether the registered nurse was present when the student nurse sustained the injury, an affirmative response of $49 \%(n=24)$ was obtained, whereas $51 \%(n=25)$ were injured without the presence of the registered nurse.

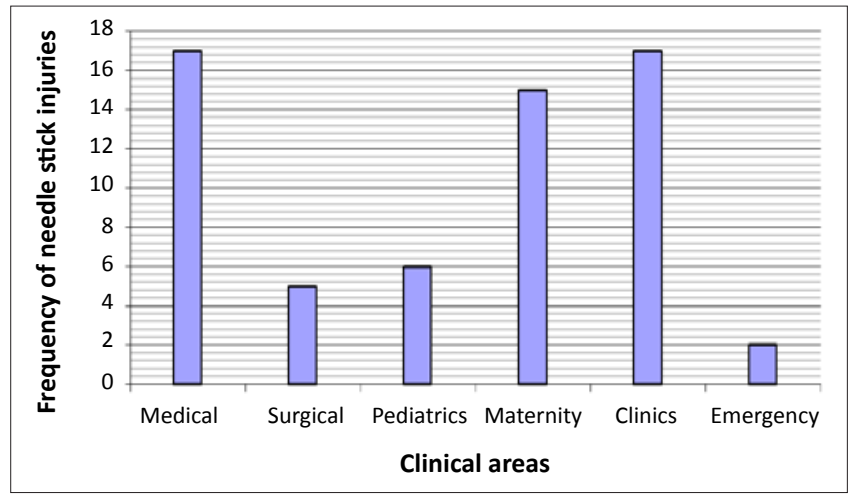

Source: Authors' original data $n$, Given as a means of number.

FIGURE 6: Clinical areas where needle-stick injuries occurred most often $\left(n=62^{2}\right)$.

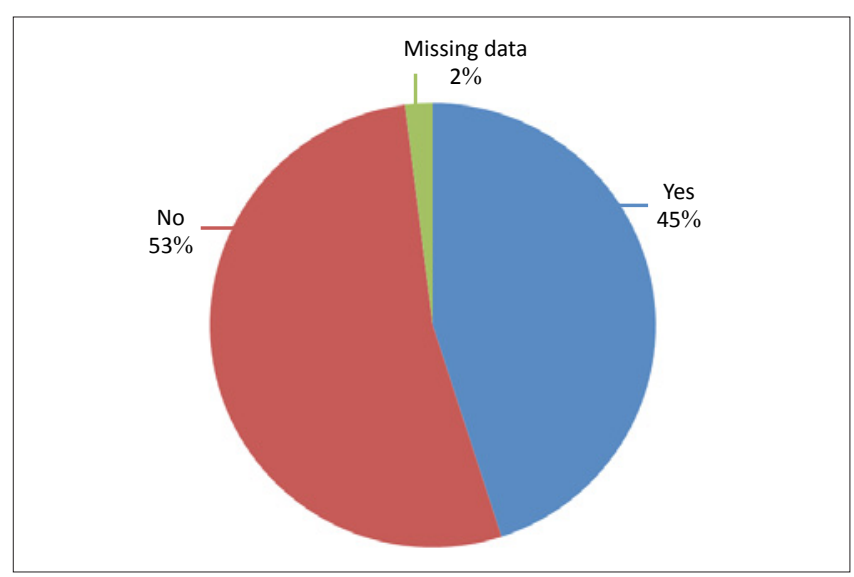

Source: Authors' original data

$n$, Given as a means of number.

FIGURE 7: Number of nursing students who received counselling after they sustained needle-stick injuries $(n=49)$.

In Haddon's matrix, the presence of a registered nurse could be regarded as representing the 'quality of communication with others' (University of Minnesota 2009:2). The role of the registered nurse in a situation where a student nurse administers an injection would be to supervise this student, to oversee the safety of the patient and the student, and to communicate to the student any possible departure from safety procedures (University of Namibia 2007:503).

From the feedback of the questionnaires it is evident that registered nurses could not provide comments regarding the administering of the injections in all instances, because they were not present at all times. Thus, with regard to the linkage of the framework of the study, communication could not have occurred optimally.

\section{Ethical considerations}

The research proposal was approved by the Research and Ethical Committee of the Faculty of Medical and Health Sciences at the University of Namibia. In addition, an oral agreement was obtained from the students after the purpose of the research study had been explained to them. Completion of the questionnaires was voluntary and the students were 2.Some students sustained more than one needle-stick injury during their training. 
assured of anonymity because no names appeared on the questionnaires.

\section{Validity and reliability}

The instrument was tested for face validity and content validity. In order to ensure face validity, the instrument was submitted to the two nursing lecturers involved with infection control at the University of Namibia as well as the co-authors. They all agreed that the instrument had face validity. Content validity was ensured by compiling the instrument on the basis of information gathered from the literature, and on the opinions of content experts such as Burns and Grove (2005:377). An agreement on content validity from two 'content' experts, namely the subject lecturer in general nursing as well as the infection control lecturer, was obtained.

In determining the reliability of the instrument, the equivalence approach was used. In this approach different observers, or raters, use an instrument to measure the same phenomena (Polit and Beck 2004:420). They compare the results afterwards. In this study two of the researchers analysed the results of the study separately and independently of each other. Both researchers obtained the same results.

\section{Limitations of the study}

A possible limitation in this study is that applicable statistics were not utilised to identify possible correlations or associations between the incidence of an injury with the different clinical areas as well as with the supervision or accompaniment of a registered nurse.

\section{Conclusions and recommendations}

The conclusions and recommendations will be based on the first two objectives of the study, namely to determine the incidence of needle-stick injuries and actions taken following the injury, as well as to describe the context in which the injury occurred. These conclusions and recommendations will incorporate Haddon's framework.

\section{The incidence of needle-stick injuries and the actions taken subsequent to such injuries}

From the analysis of the data it is evident that, during 2008 alone, some $17 \%(n=34)$ of students sustained needle-stick injuries. In addition, the accumulated percentage over all the years of training added up to $25 \%(n=49)$, meaning that once a student has completed his or her training, there is a chance of one in four that he or she will sustain a needle-stick injury. Furthermore, in only 55\% $(n=27)$ of cases were these injuries reported. The implications are that the official statistics released by the Ministry of Health and Social Services would have been incorrect. It is on these statistics that previous curriculum decisions with regard to clinical teaching and student accompaniment have been based.
Of those students who sustained needle-stick injuries, only $37 \%(n=18)$ of cases received treatment. In total, in $45 \%$ $(n=22)$ of cases the victim received counselling.

The following recommendations are submitted in terms of Haddon's framework.

\section{Considerations for the pre-injury phase}

The nursing curriculum should strengthen course content on the storage, use and disposal of sharps and needles. This includes a renewed emphasis on the guidelines and policies on needle-stick injuries.

A detailed orientation programme for each ward should be compiled in consultation with the Ministry of Health and Social Services. This would be regarded as a method to increase students' 'awareness of surroundings'.

\section{Considerations for the injury phase}

The nursing curriculum should strengthen skills in the correct wearing of gloves and treatment of the injured area.

The aspect of registered nurses accompanying nursing students should be incorporated in nursing student registers and $\log$ books.

\section{Considerations of the post-injury phase}

A new protocol is to be compiled for all nursing students. In this protocol guidance and information will be provided on when and to whom all needle-stick injuries should be reported. If anonymity is required, the phone number of a specific lecturer should be provided with the assurance that the student does not need to be identified. This lecturer should then assist the student to reflect on possible reasons why anonymity is required.

The clinical practicum study guides should incorporate reflective exercises on the implications of being injured and how to deal with inner conflict and fears. The above could be addressed in counselling sessions.

\section{The context in which needle-stick injuries occur}

It appears that most of the injuries occurred during the first and third year of training (Table 1). These injuries mainly occurred in the medical wards and the community health clinics, and, in $51 \%$ of the incidents, a registered nurse was not present when the injury occurred.

The following recommendations are submitted in terms of Haddon's framework.

\section{Considerations for the pre-injury phase}

At the beginning of the second year, a sensitisation session or day is presented for all students. This is the year in which they will be engaged more independently, as well as be exposed to the medical wards and community health clinics, 
and consequently a list or guidelines on possible hazards to be attentive to should be provided. The first-years are only allocated to the clinical area during their second year.

A session should be arranged by the Dean of the School of Nursing and Public Health with the nursing management of the Ministry of Health and Social Services. During this meeting, guidelines should be drawn up on the best way to accompany nursing students in the clinical setting.

\section{Considerations for the injury phase}

There should be constant emphasis on the presence of a registered nurse during medication administrations, specifically injections. With regard to the pre-injury phase, renewed emphasis on the guidelines and policies on needlestick injuries should be implemented.

\section{Considerations for the post-injury phase}

The very nature of the injury brings out all the inherent fears and subsequent behaviour in nursing students, leading to a situation of non-reporting and non-treatment. A counsellor unconnected to the University or nursing environment should be considered, because student nurses may feel more comfortable with a person with whom they have no contact in the classroom or the clinical environment.

\section{Directions for further research}

The experiences of nurses injured through needle-stick injuries should be explored and described. This information could enhance the support provided to them.

\section{Concluding remarks}

It is evident that needle-stick injuries do occur amongst student nurses enrolled at the University of Namibia and that the focus should be placed on selected curriculum activities as indicated in the recommendations. The enhancement of skills should be emphasised together with the facilitation of trusting 'behaviour', specifically with regard to reporting. This trusting 'behaviour' would, however, require more in-depth knowledge about the experiences of student nurses who sustained needle-stick injuries, and thus the recommendation for a research study that focuses on their experiences. The consequences of needle-stick injuries, even when there were no adverse effects, have a tremendous negative impact on the physical and emotional wellbeing of student nurses.

\section{Acknowledgements}

The authors acknowledge the contribution and input of the peer review panel of Health SA Gesondheid. In addition, this study would not have been possible without the participation of the nursing students of the University of Namibia.

\section{Competing Interests}

The authors declare that they have no financial or personal relationship(s) which may have influenced them inappropriately in writing this paper.

\section{Authors' contribution}

All authors were equally involved in the collection of data and the writing of the report.

\section{References}

Bodkin, C. \& Bruce, J., 2003, 'Health professionals' knowledge of prevention strategies and protocol following percutaneous injury', Curationis 26(4), 22-28.

Burns, N. \& Grove, S.K., 2005, The practice of nursing research: Conduct, critique and utilization, Elsevier Saunders, St Louis, MO.

E-Facts, 2011, 'Risk assessment and needle stick injuries', viewed on 04 July 2011 from http://0sha.europa.eu/en/publications/e-facts/efact40

Engelkirk, P.G. \& Burton, G.R.W., 2007, Burton's microbiology for the health sciences, Lippincott Williams \& Wilkins, Philadelphia, PA

Leliopoulou, C., Waterman, H., \& Chakrabarty, S., 1999, 'Nurses' Failure to appreciate the Risks of infection due to Needle Stick Accidents: A hospital based survey', Journal of Hospital Infections 42(1), 53-59.

Meyer, S. \& Van Niekerk, S., 2008, Nurse educator in practice, Juta, Cape Town.

Polit, D.F. \& Beck, C.T., 2004, Nursing research: principles and methods, 7th ed., Lippincot-Raven, Philadelphia.

Nursing matters, 2011, 'ICN on Preventing Needlestick Injuries', viewed 17 May 2009 and 04 July 2011, from http://www.who.int/occupational_health/ activities/2icnneed.pdf

Trim, J.C., 2004, 'Raising awareness and reducing the risk of needle stick injuries' Nursing times.net, viewed on 09 July 2009, from http://www.nursingtimes.net/ nursing-practice-clinical-research/raising-awareness-and-reducing-the-risk-ofneedlestick-injuries/199784.article

University of Minnesota, 2009, 'Needle stick injuries among health care workers', viewed on 09 July 2009, from http://enhs.umn.edu/current/6120/needle/ prevention.html

University of Namibia, 2007, HIV and AIDS resource guide, Faculty of Medical and Health, University of Namibia, Windhoek.

Uys, L.R. \& Gwele, S., 2005, Curriculum development in nursing: Process and innovation, Routledge, New York. http://dx.doi.org/10.4324/9780203313343

Wilburn, S.Q., 2004, 'Needlestick and sharps injury prevention', Online journal of issues in nursing 9(3), 1-13, viewed on 04 July 2011, from http://www.nursingworld. org/ojin/topic25/tpc25 4.htm

Ziady, L.E. \& Small, N., 2004, Prevent and control infection, Juta, Cape Town. 